\title{
O TRGOVINI HRVATSKIH SLOBODNIH KRALJEVSKIH GRADOVA U 17. STOLJEĆU
}

\begin{abstract}
Ovaj rad predstavlja pokušaj uvida u trgovinu slobodnih kraljevskih gradova Hrvatsko-Slavonskog Kraljevstva u 17. stoljeću. Na temelju dosadašnjih rezultata historiografije te objavljenih i neobjavljenih izvora autor obrađuje prvenstveno slobodne kraljevske gradove: Zagreb (Gradec), Varaždin i Koprivnicu te u manjoj mjeri Senj i Križevce. Zagreb je od početka 17. stoljeća imao središnju ulogu pri unutarnjoj razmjeni dobara unutar Hrvatsko-Slavonskoga Kraljevstva; u djelovanju trgovaca u Varaždinu u znatnoj je pak mjeri vidljiva briga oko opskrbe vojnih posada Vojne krajine, dok su Koprivnica, Senj i Križevci bili gradovi u kojima su se ispreplitale civilne i vojnokrajiške vlasti.
\end{abstract}

Ključne riječi: trgovina; slobodni kraljevski gradovi Hrvatsko-Slavonskog Kraljevstva; 17. stoljeće; sajmovi.

\section{UVOD}

Od početka ranoga novog vijeka odvijale su se promjene $u$ gospodarskim kretanjima u srednjoistočnoj Europi koje nisu mimoišle ni zemlje pod vlašću Krune Sv. Stjepana. U Ugarskoj se početkom 17. stoljeća dogodio gospodarski pad, nakon toga je od oko 1610. do oko 1620. slijedio privremeni oporavak. U vrijeme Tridesetogodišnjeg rata slijedilo je postupno opadanje gospodarstva. Agrarna je konjunktura stala, a od 1620. dolazi do ogromnog pada cijene žitarica i krupne stoke. Uz međunarodna zbivanja, na gospodarska kretanja utjecale su i unutarnje nestabilnosti. Krupno plemstvo nastojalo je prebaciti teret krize na slobodne kraljevske gradove, seljaštvo i ugarske trgovce. Usprkos krizi, Ugarska je ostala dijelom srednjoeuropskih gospodarskih tokova. Ugarski trgovci morali su prestrukturirati svoje poslovanje, a jedna od osnovnih promjena bila je vezana uz činjenicu da se $u$ vrijeme općeg ratnog stanja sve više ljudi željelo baviti trgovinom, a to je u konačnici poskupljivalo robu. Stoga se nisu promijenili struktura i smjer trgovine već je došlo do promjene načina usmjeravanja i raspodjele dobiti, koja se smanjila. To je djelomično bilo rezultat nadmetanja ra- 
znih interesnih skupina. ${ }^{1} \mathrm{U}$ kontekstu tih zbivanja u ovom se članku pokušava prikazati temeljni uvod u trgovinu hrvatskih slobodnih i kraljevskih gradova, što može poslužiti kao osnova za buduća iscrpnija istraživanja.

Sa željom da se pruži pojašnjenje kako se odvijao trgovački život u hrvatskoslavonskim slobodnim i kraljevskim gradovima u 17. stoljeću, obavijesti o trgovačkom životu strukturirane su i inspirirane modelom Fernanda Braudela, koji je oprezno gradio istraživanja „od jednostavnog ka složenijem“2 ${ }^{\prime 2}$ pa se u ovom članku prvo predstavljaju instrumenti razmjene: gradske tržnice s dnevnim i tjednim trgom, trgovine (dućani), godišnji sajmovi, zatim slijede primjeri pojedinih trgovaca, a na kraju je predstavljen pokušaj geografskog definiranja trgovinskog optjecaja.

Razlog zašto su upravo slobodni i kraljevski gradovi uzeti kao istraživačko polazište nazire se u činjenici da se, zahvaljujući posebnosti njihova političkog $i$ društvenog statusa, u njima mogao organizirati drugačiji tip gospodarskih djelatnosti u odnosu na trgovišta uklopljena u sustav vlastelinstava ili na seoska naselja. U članku je predstavljeno pet slobodnih i kraljevskih gradova Hrvatsko-Slavonskog Kraljevstva, od kojih su tri (Senj, Križevci i Koprivnica), zbog nazočnosti vojnokrajiških posada, imali izrazito dvojni, vojno-civilni, karakter. I Varaždin je imao vojni utjecaj, ali u znatno manjoj mjeri. Slobodni i kraljevski grad Zagreb (Gradec) bio je jedino potpuno civilno naselje, bez utjecaja vojnokrajiških vlasti na njega.

Tijekom 17. stoljeća spomenuti gradovi imali su različit prometni položaj. ${ }^{3}$ Iako je bio jedini lučki grad, Senj sve više zaobilaze kopneni prometni pravci iz unutrašnjosti koji se sve više usmjeravaju prema Bakru, Kraljevci, Bakarcu i ostalim zrinskim lukama na sjevernom Jadranu, odnosno prema habsburškoj Rijeci. Prometni gubitnik dijelom su bili i Križevci, a u manjoj mjeri i Koprivnica jer se tim gradovima granica Osmanskog Carstva približila na svega desetak kilometara. Varaždin je bio među dobitnicima smanjenja trgovine tzv. Ljubljanskom cestom, kojom je u drugoj polovici 16. stoljeća dominirao promet. Drugi

\footnotetext{
1 Zsigmond PÁL PACH, Hungary and the European Economy in Early Modern Times, Abingdon: Routledge 1994; Pál FODOR, Trade and Traders in Hungary in the age of Ottoman Conquest: an Outline. Acta Orientalia Academiae Scientiarum Hungaricae, Vol. 60, No. 1, Budapest 2007, 1-8; Géza PÁLFFY, Povijest Mađarske. Ugarska na granici dvaju imperija (1526.-1711.), Samobor: Meridijani 2010., 205-213.

2 Fernand BRAUDEL, Igra razmjene, Zagreb: August Cesarec, 1992., 11.

3 Petar FELETAR, Hrvatske povijesne ceste. Karolina, Jozefina i Lujzijana, Zagreb - Samobor: Meridijani 2016., 31-40; Dragutin FELETAR, Petar FELETAR, Hrvoje PETRIĆ, O kopnenom i riječnom prometu s osvrtom na posjede Zrinskih i Frankopana, u: Zrinski - od bribirskih Šubića do čakovečkih Zrinskih (1102.-1347.-1546.-1671.-1703.), Zbornik radova s međunarodnog znanstvenog skupa Čakovec-Sisak, 26. i 27. X. 2018. godine, Čakovec: Letis d.o.o. i Zrinska garda Čakovec, 2019., 85-102, i tamo navedena literatura.
} 
dobitak bio je povezan s činjenicom da se taj grad našao na prometnici koja je povezivala zrinske posjede $\mathrm{u}$ Međimurju s onima smještenim jugozapadno te njihovima lukama na sjevernom Jadranu. Na tom se pravcu našao i slobodni kraljevski grad Zagreb (Gradec), koji je također u gospodarskom smislu bio sve više orijentiran prema unutarnjoaustrijskim teritorijima na zapadu. To je važno i zbog činjenice što direktna trgovina hrvatske unutrašnjosti sa sjevernojadranskim lukama nije premašivala opseg trgovine koja se vodila prema unutarnjoaustrijskim pokrajinama u kojoj su vodeću ulogu imali građani Zagreba, ali i Varaždina. ${ }^{4}$

\section{Osvrt na dosadašnju historiografiju}

Jedan od prvih objavljenih prikaza cjelovite trgovine na prostoru Hrvatskoslavonskog kraljevstva u 17. stoljeću dan je u knjizi Rudolfa Horvata ${ }^{5}$. Vrlo je malo podataka o trgovini u slobodnim i kraljevskim gradovima 17. stoljeća i u knjizi Josipa Adamčeka ${ }^{6}$, baš kao i u Enciklopediji hrvatske povijesti i kulture ${ }^{7}$. Zbog toga se valja osvrnuti na radove o trgovini u pojedinim gradovima. Do sada je najviše radova napisano o Zagrebu i Varaždinu, dok je istraživanje trgovine u 17. stoljeću u Koprivnici, Križevcima i Senju jedva dotaknuto. Na ovome mjestu osvrnut ću se na najvažnije radove, a one koji tek periferno spominju trgovinu 17. stoljeća ili neke njezine segmente donosim u bilješkama u ovom radu; napominjem i kako su se na neke aspekte senjske trgovine u 17. stoljeću fragmentarno osvrnuli Mile Magdić ${ }^{8}$ i Catherine Wendy Bracewell ${ }^{9}$, dok su se trgovinom drvom bavili Bogumil Hrabak ${ }^{10}$ i Nataša Štefanec ${ }^{11}$. Na križevačku se trgovinu kratko

$\overline{4}$ Josip ADAMČEK, Trgovačke veze sjeverne Hrvatske s Primorjem u XVI i XVII stoljeću, Dometi, 10, Rijeka, 1977., 82.

5 Rudolf HORVAT, Povijest trgovine, obrta i industrije u Hrvatskoj, Zagreb: AGM, 1994. Problem je u tome što je knjiga otisnuta tek 1994. te priređena na osnovi rukopisa napisanog 1926.-27. Za tisak je knjigu priredila Mira KOLAR-DIMITRIJEVIĆ.

6 Josip ADAMČEK, Agrarni odnosi u Hrvatskoj od sredine XV do kraja XVII stoljeća, Zagreb: Jugoslavenska akademija znanosti i umjetnosti, 1980.

7 Igor KARAMAN i suradnici, Trgovinska privreda, u: Enciklopedija hrvatske povijesti $i$ kulture, Zagreb: Školska knjiga, 1980., 689. Natuknice o povijesti gradova Koprivnice, Križevaca i Senja ne donose nikakve podatke o trgovini tih gradova u 17. stoljeću, dok nešto podataka ima za Varaždin i Zagreba, usp. str. 307, 325, 577, 713, 751 .

8 Mile MAGDIĆ, Senj u XVII. stoljeću, Kolo, 6, 1910., 57-58.

9 Catherine Wendy BRACEWELL, Senjski uskoci, Zagreb: Barba, 1997., 108-118.

10 Bogumil HRABAK, Regionalna i međunarodna trgovina Mlečana i Dubrovčana drvetom iz Senja (XIV-XVIII stoljeće), Radovi Zavoda za hrvatsku povijest, 24, Zagreb, 1991., 105.

11 Nataša ŠTEFANEC, Trgovina drvetom na Triplex Confiniumu ili kako izvući novac iz senjskih šuma (1600-1630)?, u: Triplex Confinium (1500.-1800.): ekohistorija: zbornik radova s 3. međunarodnog znanstve- 
osvrnuo Neven Budak ${ }^{12}$, a na koprivničku Dragutin Feletar. ${ }^{13}$ Novije spoznaje o koprivničkoj trgovini u 17. stoljeću predstavio je Hrvoje Petrić. ${ }^{14}$ Prvi potpuni osvrt na stariju zagrebačku trgovinu predstavlja rad Ivana Krstitelja Tkalčića, no on se tek malim dijelom oslanja na sam početak 17. stoljeća. ${ }^{15}$ Iako pretežito piše o trgovcu Leonardu Mülbacheru iz biskupsko-kaptolskog Zagreba, Josip Matasović dijelom je predstavio i trgovinu slobodnoga kraljevskog grada Zagreba (Gradeca). ${ }^{16}$ Idući korak u poznavanju zagrebačke trgovine u 17. stoljeću predstavlja kratki, ali sadržajni rad Igora Karamana. ${ }^{17}$ Iako se bavi zagrebačkom trgovinom i 18. i 19. stoljeća, niz izuzetno vrijednih obavijesti o 17. stoljeću donosi Zlatko Herkov ${ }^{18}$. Od ostalih priloga koji obrađuju zagrebačku trgovinu vrijedi istaknuti poglavlje o trgovini u Zagrebu u 17. stoljeću u knjizi Franje Buntaka. ${ }^{19}$ O varaždinskim trgovcima u 17. stoljeću najpotpunije je pisala Višnja Burek ${ }^{20}$, iako postoje i raniji vrijedni doprinosi koji se odnose na pojedine segmente varaždinske trgovine, a napisali su ih Krešimir Filićc ${ }^{21}$, Mirko Androić ${ }^{22}$, Mira Ilija-

nog skupa, ROKSANDIĆ, Drago; ŠTEFANEC, Nataša; GLUNČIĆ-BUŽANČIĆ, Vinka; MIMICa, Ivan (ur.). Split - Zagreb: Književni krug, Zavod za hrvatsku povijest, 2003., 337-365.

Neven BUDAK, Društveni i privredni razvoj Križevaca, u: Križevci - grad i okolica, Zagreb: Institut za povijest umjetnosti, 1993., 43.

Dragutin FELETAR, Podravina, Koprivnica: Muzej grada Koprivnice, 1988., 106.

Hrvoje PETRIĆ, Koprivnica u 17. stoljeću. Okoliš, demografske, društvene i gospodarske promjene u pograničnom gradu, Samobor: Meridijani 2005., 174-180. Taj se članak, vezano uz koprivničke trgovce, djelomično oslanja na spoznaje dobivene istraživanjem predstavljenima u knjizi.

Ivan TKALČIĆ, O staroj zagrebačkoj trgovini, Rad JAZU, Zagreb 1909., knj. 176, 177-238; knj. 178, 87-114; objedinjeno objavljeno i u: Ivan TKALČIĆ, O staroj zagrebačkoj trgovini i obrtima, priredila Agneza SZABO, Zagreb: Dom i svijet, 1999. Na 17. stoljeće odnosi se tekst na str. 110-122.

Josip MATASOVIĆ, Knez Lenard kaptolma zagrebačkoga kramar, Narodna starina, sv. 28, 99-114; sv. 29, 169-204, Zagreb, 1932.; isto, sv. 32, 187-252, Zagreb, 1933.; isto, sv. 33, 15-32; sv. 34, 125-138, Zagreb, 1934.; isto, sv. 35, Zagreb, 1935., 59-54. Članci su kasnije skupljeni u knjigu: Josip MATASOVIĆ, Knez Lenard, kaptoloma zagrebečkoga kramar, Zagreb: Dora Krupićeva, 2009.

Igor KARAMAN, Zagrebački trgovci u 17. i 18. stoljeću, Historijski zbornik, godina XXIX - XXX, Zagreb, 1977., 251-262.

Zlatko HERKOV, Povijest zagrebačke trgovine, Zagreb: Jugoslavenska akademija znanosti i umjetnosti, 1987.

Franjo BUNTAK, Povijest Zagreba, Zagreb: Nakladni zavod Matice hrvatske, 1996., 414-428. Ta je knjiga napisana prije autorove smrti 1985., a za tisak ju je priredio Mladen ŠVAB, tako da se autor u njoj nije mogao osvrnuti na doprinos Zlatka Herkova.

Višnja BUREK, Otkrivanje gradskih tajni. Varaždin u 17. stoljeću, Zagreb - Varaždin: Hrvatska akademija znanosti i umjetnosti - Zavod za znanstveni rad u Varaždinu, 2019., 279-300.

21 Ana KANIŠKI, Doprinos Krešimira Filića istraživanju trgovačke obitelji Praunsperger iz Varaždina, Radovi Zavoda za znanstveni rad Varaždin, 23, 2012., 257-268.

22 Mirko ANDROIĆ, Varaždinski trgovac Vinko Perger, Kaj 10, Zagreb 1968., 63-64; isti, Stari putovi tekstila u svijetu i u nas, u: Textil import-export, Zagreb, 1952. - 1977., Varaždin, 1977., 37-38, i drugi radovi toga autora. 
nić ${ }^{23}$, Slavko Kapustić24 i Ana Kaniški. ${ }^{25}$ Usprkos mnogim vrijednim prilozima, ne postoji obrada trgovinskoga gospodarstva hrvatsko-slavonskih slobodnih kraljevskih gradova u 17. stoljeću kao cjeline.

\section{Tržnice}

Dnevni i tjedni sajmovi zapravo su predstavljali tržnice, a na njima se, uz građane, opskrbljivalo stanovništvo koje je spadalo u gradsku gravitacijsku zonu. Dnevni i dva tjedna sajma (ponedjeljkom i četvrtkom) u slobodnom i kraljevskom gradu Zagrebu (Gradecu) bili su regulirani još Zlatnom bulom 1242. godine. Dnevni sajmovi bili su ograničeni na trgovinu robom za svakodnevnu upotrebu, dok su tjedni sajmovi imali važniju ulogu jer su na njima domaći obrtnici i trgovci prodavali svoju robu. Glavni tržni prostori bili su na središnjem gradečkom trgu oko crkve sv. Marka i na trgu kaptolsko-biskupskog Zagreba ispred utvrde katedrale. ${ }^{26}$

Tjedni sajam u Varaždinu održavao se četvrtkom, što je vidljivo primjerice 1430. godine, a možda se već u srednjem vijeku tjedni sajam održavao i subotom; postojali su i dnevni trgovi. U Varaždinu se dnevni trg održavao na prostoru današnjeg središnjeg trga, a sajam na sajmištu Ciglenici. ${ }^{27}$ Koprivnica je privilegij održavanja tjednih sajmova ponedjeljkom imala od 4. studenoga $1356 .{ }^{28}$, a kao dokaz zadržavanja tjednog sajma i u 16. stoljeću može nam biti odluka Sabora od 15. ožujka 1562. u kojoj se, između ostalih, spominje i koprivnički tjedni sajam. ${ }^{29}$ Sajmovi su se održavali i početkom 17. stoljeća. Tako je naprimjer iz 1635.

23 Mira ILIJANIĆ, Nekoliko podataka o vezama Ptuja i Varaždina u 16. i 17. stoljeću, Ptujski zbornik, IV, Ptuj, 1975., 289-293.

24 Slavko KAPUSTIĆ, Nekoliko riječi o organizaciji trgovine s graničarima u Varaždinu 17. stoljeća, Zbornik radova Fakulteta organizacije i informatike Varaždin, 2-3, Varaždin, 1979., 395-404; isti, Trgovačke veze Vincenca Pergera, trgovca iz Varaždina, s iglavskim trgovcem Joachimom Kopenkhom, Zbornik radova Fakulteta organizacije i informatike, 5, Varaždin 1981., 3-20; isti, O borbi za tržište soli u Varaždinu 17. stoljeća, Zbornik radova Fakulteta organizacije i informatike u Varaždinu, 5, Varaždin 1981., 21-26.

Ana KANIŠKI, Kapela Sv. Josipa u franjevačkoj crkvi u Varaždinu: ikonografija i naručitelj, Tkalčić, 16, Zagreb, 2012., o varaždinskom trgovcu Danijelu Praunspergeru na str. 344-359.

Emilije LASZOWSKI, Prilog za povijest sajmova u Hrvatskoj i Slavoniji, Vjestnik kr. Hrvatsko-slavonsko-dalmatinskog Zemaljskog arhiva, IV/2, Zagreb, 1902., 79.

LASZOWSKI, Prilog za povijest sajmova u Hrvatskoj i Slavoniji, 78; Neven BUDAK, Gradovi Varaždinske županije u srednjem vijeku, Zagreb - Koprivnica: Meridijani, 1994., 78-79; HORVAT, Povijest trgovine, obrta i industrije u Hrvatskoj, 50; Jasmin MEDVED, Trgovina grada Varaždina u XV. stoljeću, Radovi Zavoda za znanstveni rad HAZU Varaždin, 24, Varaždin, 2013., 641-646. 
sačuvana odredba u kojoj se spominje postojanje sajmova u Koprivnici ${ }^{30}$, gdje su se dnevni i tjedni trgovi isprva održavani unutar utvrde, a kasnije na prostoru sjeverno od nje, na kojem se u 17. stoljeću formirao novi trg. ${ }^{31}$

\section{Trgovine - dućani}

U slobodnom i kraljevskom gradu Zagrebu na Markovu trgu bile su smještene drvene trgovine koje su davane u najam domaćim trgovcima. Te su se trgovine morale ukloniti nakon 1639. godine. Trgovine su bile smještene i u prizemlju nove kaptolske vijećnice (podignute nakon 1674.). ${ }^{32}$

Jedna od trgovina bila je u vlasništvu Martina Kovačića, a nalazila se kraj crkve sv. Marka (s iznajmljenim skladištem u Dvercima). Kovačić je u toj trgovini prodavao tkanine, željezo, začine i drugu robu. ${ }^{33}$

Zahvaljujući zapisima u tridesetničkim knjigama, moguće je vidjeti koja se roba pojavljivala u zagrebačkim trgovinama u 17. stoljeću. Uz domaće proizvode te one uglavnom s europskog zapada, bilo je i prekomorskih artikala. Na zagrebačkom tržištu mogle su se naći brojne vrste živežnih namirnica, proizvoda od željeza te drugih metala, razne vrste tekstila i kože, začina, smole, svijeća, sapuna, voska, stakla, brusova za kose, gume, duhana, posuđa, kremena itd. ${ }^{34}$

Zanimljivo je da je gvardijan koprivničkog franjevačkog samostana Pavao Pribojević 25. ožujka 1610. dao dopuštenje Petru Kramaru ili Zolaru (Solaru) da

30 Hrvatski državni arhiv (dalje: HDA), HR-HDA-426, Ujedinjena bansko-varaždinsko-karlovačka generalkomanda, Uvezeni spisi Varaždinskog generalata, knj. 1, fol. 86v-87v.

U Koprivnici je postojao običaj prema kojemu se tjedni sajam držao u nedjelju umjesto u ponedjeljak, kako je određeno privilegijem. To se protivilo zaključcima Sabora od godina 1611. i 1629., koji su zabranili trgovanje u nedjelju i blagdane. Zato je Sabor, koji se 14. travnja 1689. sastao u Zagrebu, uputio grad Koprivnicu da tjedni sajam zbog pobožnosti premjesti s nedjelje na koji djelatni dan. Gradski magistrat u Koprivnici nije poslušao Sabor, pa je ostao kod prijašnjeg običaja. O tome se raspravljalo na Saboru u Želinu 22. ožujka 1691. Sabor je po želji zagrebačkog biskupa Aleksandra Mikulića obnovio svoje zaključke od godina 1611., 1629. i 1689. Kako se grad Koprivnica nije držao tih zaključaka, Sabor je odredio da križevački podžupan Baltazar Patačić ode u Koprivnicu i opomene Gradski magistrat da se prilagodi donesenim zaključcima. Kako podžupanova opomena nije koristila, dozvolio je Sabor, održan u Zagrebu 7. svibnja 1691., zagrebačkom biskupu da protiv grada Koprivnice odredi na sjednici duhovnog stola crkvenu kaznu. Koprivničani su nastavili držati tjedni sajam u nedjelju, a to je biskupu dojavio Tomo Čuz, koji je time na sebe navukao mržnju koprivničkih građana te se bojao njihove osvete. O tome se raspravljalo na Saboru u Zagrebu 7. ožujka 1693. Sabor je biskupa uputio neka po križevačkom podžupanu poduzme sva pravna sredstva; ujedno je odredio globu koju je Gradski magistrat Koprivnice morao platiti za svaki sajam koji bi se održao u nedjelju. Zaključci Hrvatskog sabora (dalje: ZHS), knj. 1, Zagreb 1958., 511, 526, 527, 564; Rudolf HORVAT, Poviest slob. $i$ kr. grada Koprivnice, Zagreb, 1943., 272-273. 
na samostanskoj zemlji uz crkvu u Koprivnici drži svoju trgovinu. ${ }^{35}$ Pitanje je znači li prezime Kramar zanimanje lokalnog trgovca (kramara) i ukazuje li drugo prezime, Solar, na trgovca solju. Vezano uz lokaciju njegove trgovine, poznato je da se tadašnji koprivnički franjevački samostan nalazio u neposrednoj blizini današnje župne crkve sv. Nikole, te se lako može zaključiti da se trgovina početkom 17. stoljeća, odvijala na prostoru unutar bedemima ograđene koprivničke gradske jezgre. Idućih desetljeća trgovačke i sajmene funkcije postupno su bile premještene izvan gradskih utvrda. ${ }^{36}$

\section{Godišnji sajmovi i izvozni trg}

Najveću ulogu za razvoj trgovine ranonovovjekovnih gradova imali su godišnji sajmovi jer su na njih mogli dolaziti strani trgovci bez plaćanja daća. ${ }^{37} \mathrm{U}$ kaptolsko-biskupskom Zagrebu godišnji se sajam održavao na dan Sv. Stjepana kralja - tzv. Kraljevo (20. kolovoza), dok je najstariji u slobodnom i kraljevskom gradu Zagrebu (Gradecu) godišnji sajam bio onaj oko Sv. Marka (25. travnja). Taj je sajam počinjao osam dana prije toga blagdana, a završavao osmog dana nakon njega. Gradec je još od srednjega vijeka imao sajam na dan Sv. Margarete (13., odnosno 20. srpnja), a 1569. dobio je pravo održavanja sajma ,in festo Conceptionis beatissimae Mariae Virginis ${ }^{\text {“38. }}$.

U prvoj polovici 17. stoljeća počeo se održavati i Božićni sajam, a sajam na Kraljevo postao je 1633. zajedničkim sajmom kaptolsko-biskupskog Zagreba i Gradeca ${ }^{39}$, pa se npr. 1650. godine u Gradecu spominju: „,czuetni zaniam“, „markouzky zenyem“, „na Margetinye“, „na Kralyeuo“ i „bosichny zenyem“" ${ }^{40}$ Kralj Ferdinand III. odobrio je 1655. još dva sajma: na utorak Duhova („Trojački“ sajam) i nedjeljom prije blagdana Sv. Šimuna i Jude apostola (28. listopada). ${ }^{41}$ Pove-

35 Paškal CVEKAN, Koprivnica i Franjevci, Koprivnica, 1989., 66.

PETRIĆ, Koprivnica u 17. stoljeću, 176-180.

O sajmovima na prostoru habsburških zemalja, usp. Wilhelm Rausch, JAHRMÄRKTE, Messen und Stadentwicklung in den habsburgischen Ländern Österrichs, u: Peter JOHANEK und Heinz STOOB, Europäische Messen und Märktesysteme in Mittelalter und Neuzeit, Köln - Weimar - Wien, 1996., 171-187.

Emilij LASZOWSKI, Povjestni spomenici slob. kralj. grada Zagreba (dalje za cijelu seriju Povijesnih spomenika Zagreba: PSZ), knj. 15, Zagreb, 1937., 59; LASZOWSKI, 79.

HERKOV, Povijest zagrebačke trgovine, 24.

40

PSZ, knj. 19, 162-163.

41 LASZOWSKI, Prilog za povijest sajmova u Hrvatskoj i Slavoniji, str. 79. Kralj je u povelji odredio: „Mi zbog toga svim trgovcima i tršcima dajemo punu sigurnost i zaštitu da na te slobodne godišnje sajmove koje smo rečenom gradu odobrili, slobodno i sigurno dolaze sa svom robom i stvarima i dobrima i to bez ikakva straha ili bojazni s obzirom na svoju osobu, na svoje stvari i trgovačku robu, i da se - dovršivši ovdje svoje poslove i trgovanje - slobodno vrate svjim kućama ili u mjesto 
ćanje broja godišnjih sajmova s četiri na sedam jedan je od pokazatelja snaženja zagrebačke trgovine tijekom 17. stoljeća.

U vrijeme godišnjih sajmova putujući su trgovci koristili i prostor podgrađa u blizini zdenca Manduševca. U vrijeme sajma na dan Sv. Margarete koristio se i prostor oko te crkve. Gradečka gradska uprava nastojala je proširiti tržni prostor uz Manduševac, pa je 1641. naredila vlasnicima ustupanje dijela vrtova i okućnica radi proširenja sajmišta. Kako je na tome trgu bilo sjedište carinarnice zvane tridesetnica, a na mađarski riječ harminc znači trideset, tržni prostor dobio je naziv Harmica. ${ }^{42}$

Varaždin je sajam imao od 1406. godine, kada je kralj Žigmund građanima odobrio da sami izaberu dan za godišnji sajam. Varaždin je novi sajamski privilegij za godišnje sajmove dobio 2 . veljače 1448. od varaždinskoga gospodara Ulriha Celjskog, a taj se sajam održavao na dan Sv. Jakova apostola (25. srpnja). Spomenuti se sajam trebao održavati osam dana prije i poslije Jakovljeva. Ban Ivan Vitovac 25. srpnja 1462. prenio je održavanje toga sajma na četvrti dan nakon blagdana Sv. Jakova jer su ranije određeni dani sajmovanja bili nespretni zbog održavanja sajmova $u$ isto vrijeme $u$ obližnjim gradskim naseljima. Ta se promjena nije održala jer je 1550. kralj potvrdio raniji privilegij bana Ulriha Celjskog s pripadajućim datumom sajma. Treba spomenuti i da se 1509. spominje godišnji sajam na dan Sv. Šimuna i Jude (28. listopada). Sajam na dan Sv. Jakova bio je oslobođen plaćanja tridesetina, a grof Celjski odredio je da su svi trgovci koji su prolazili Varaždinom morali svoju robu izložiti tamo na prodaju. Radilo se o tzv. Niederlaghu, koji je bio često pravo na prostoru Svetog Rimskog Carstva. ${ }^{43}$

Izgleda da se na spomenute ranije sajamske povlastice zaboravilo, pa je na prijedlog Sabora kralj Matija 1618. Varaždinu podijelio Niederlaghna način da su svi trgovci koji su svoju robu uvozili u hrvatske zemlje ili su je iz nje izvozili robu morali na nekoliko dana izložiti na prodaju u Varaždinu. Dodatan značaj Varaždinu daje i činjenica što je tamo bilo glavno skladište soli za Međimurje i Slavonsku vojnu krajinu. ${ }^{44}$

kamo žele, razumije se uvijek pod našom zaštitom i osiguranjem." HERKOV, Povijest zagrebačke trgovine, 6.

HERKOV, Povijest zagrebačke trgovine, 24; KARAMAN, Zagrebački trgovci u 17. i 18. stoljeću, 258259.

43 LASZOWSKI, Prilog za povijest sajmova u Hrvatskoj i Slavoniji, 78; Neven BUDAK, Gradovi Varaždinske županije u srednjem vijeku, Zagreb-Koprivnica: Nakladna kuća dr. Feletar, 1994., 78-79; HORVAT, Povijest trgovine, obrta i industrije u Hrvatskoj, 50; Jasmin MEDVED, Trgovina grada Varaždina u XV. stoljeću, Radovi Zavoda za znanstveni rad HAZU Varaždin, 24, Varaždin, 2013., 641-646. 
Poznato je da je sajmeni prostor bio na Ciglenici, koja se nalazila izvan gradskih zidina $\mathrm{u}$ istoimenom predgrađu. Adolf Wissert Ciglenicu je locirao sjeverno od Staroga grada, u blizinu sadašnje Vodnikove ulice. Smještaj sajmišta na prostor nedaleko od sjevernih gradskih vrata ne treba čuditi jer su se na tome mjestu spajale ceste iz Ptuja i Zagreba, a u blizini je bila i luka na rijeci Dravi. Toponim Ciglenica često se spominje u 16. i 17. stoljeću, no u idućem se stoljeću gubi. Upravo je tijekom 17. stoljeća Ciglenica, između drugih varaždinskih suburbija, spadala u prostore najintenzivnije urbanizacije. ${ }^{45} \mathrm{Na}$ osnovi cjenika varaždinskog trga iz 1658. - 1659.96, kao i računa varaždinskih gradskih primitaka i izdataka za $1688 .{ }^{47}$ i 1691 . godinu ${ }^{48}$ moguće je napraviti detaljnu analizu vrsta robe koja se prodavala u Varaždinu. Zbog ograničenog prostora u ovom članku, istraživanja tih izvora potrebno je napraviti u zasebnom tekstu.

Dolazak trgovaca iz udaljenih krajeva na varaždinske sajmove bio je povezan s velikim rizicima jer su trgovca na putovima dočekivali odbjegli vojnici, razbojnici i buntovni seljaci. Među opasnim cestama bile su one koje su vodile iz Štajerske u Varaždinu i od Varaždina preko Ludbrega do Koprivnice. ${ }^{49}$

Senj je godišnji sajamski privilegij na dan Sv. Petra i Pavla dobio 1489. godine, a u 17. stoljeću ustanovljen je još jedan sajam. Dana 23. veljače 1652. kralj Ferdinand odobrio je žiteljima Senja „da mogu, kao oko Jurjeva, takodjer i na dan sv. Mihajla arkangjela i nekoliko dana prije i poslie toga blagdana u svome gradu obdržavati godišnji sajam, ali samo pod tom pogodbom, da moraju dohodke ovih obadvaju sajmova upotrebiti za uzdržavanje sudaca i činovnika grada Senja. ${ }^{\text {“50 }}$

U križevačkom Gornjem gradu sajam se održavao četiri dana prije i nakon svetkovine Sv. Ladislava, što možemo saznati 1382., kada je kralj potvrdio raniji privilegij. ${ }^{51}$ Od kasnog 15. stoljeća počinje nazadak Križevaca, a gospodarski

$\overline{45}$ Mira ILIJANIĆ, Slavko KAPUSTIĆ, Prilog istraživanju stanovništva i urbanog razvoja Varaždina do zaključno 16. stoljeća, Varaždinski zbornik, Varaždin 1983, str. 173, 175; Višnja BUREK, Urbanistički razvoj varaždinskih suburbija tijekom 17. stoljeća, Historia Varasdiensis, 1, Varaždin, 2011., 99-100, 102; Medved, Trgovina grada Varaždina u XV. stoljeću, 463.

Julije JANKOVIĆ, Dva cjenika za trg slob. i kralj. grada Varaždina 1658-1749, Starine, knj. 26, Zagreb, 1893., 1-19.

DAV, Arhiv grada Varaždina, Radikalni arhiv, 958 XLVII-751.

DAV, Arhiv grada Varaždina, Radikalni arhiv, , 960 XLVII-753.

Ante GABRIČE.

DAV, Arhiv grada Varaždina VIĆ, Stanovništvo Varaždina tijekom minulih stoljeća, Zagreb - Varaždin: Zavoda za znanstveni rad HAZU Varaždin, 2002., 77.

Mile MAGDIĆ, Tri sajamska privilegija za grad Senj, Vjestnik Kr. hrvatsko-slavonsko-dalmatinskog zemaljskog arkiva, 2, Zagreb, 1900., 109-113; LASZOWSKI, Prilog za povijest sajmova u Hrvatskoj i Slavoniji, str. 76.

51 Tadija SMIČIKLAS, Diplomatički zbornik Kraljevine Hrvatske, Dalmacije i Slavonije, 16, Zagreb: JAZU 1976., 257-258. 
oporavak u 17. stoljeću bio je ograničen u odnosu na ostale hrvatske slobodne i kraljevske gradove. ${ }^{52}$ Činjenica da u Križevcima tijekom 17. stoljeća nije utemeljen novi sajam možda ukazuje na nerazvijenost trgovine, no pri tome treba biti oprezan.

U razvoju trgovine u Hrvatsko-Slavonskom Kraljevstvu u 17. stoljeću važnu je ulogu imalo stvaranje trgova za izvozne proizvode. Hrvatsko-slavonski sabor 1610. godine donio je odluku o uvođenju posebnih trgova na koje su svi izvoznici morali dovoziti svoju robu za izvoz. Na te su trgove (loca depositionis) trebali dolaziti stranci i tamo kupovati izvozne proizvode poput meda, svinja, goveda, žitarica itd. Time je Hrvatsko-slavonski sabor htio riješiti sukob hrvatskog plemstva sa štajerskim i kranjskim staležima oko carine i mitničarine, koja se nametala njihovoj robi u Štajerskoj i Kranjskoj..$^{53}$

\section{Trgovci - izabrani primjeri}

Domaći trgovci u slobodnom i kraljevskom gradu Zagrebu (Gradecu) bili su uglavnom bez većih poduzetničkih ambicija. Od njih je donekle odskakao Martin Kovačić, koji je bio senator, a neko vrijeme i gradski sudac. Očito je koncentrirao dovoljnu količinu novca jer je isusovcima, za gradnju samostana, mogao posuditi 100 dukata. ${ }^{54}$

Neki trgovci, poput Lucijana (Lucius) Calcinellija, poslovali su i u slobodnom kraljevskom gradu Zagrebu (Gradecu) i kaptolsko-biskupskom Zagrebu (gdje je imao ortaka). Trgovac Lucijan započeo je trgovački uspon u kaptolsko-biskupskom Zagrebu, a potom je prešao u Gradec. On je svoj kapital stekao iskoristivši potrebe za opskrbom u tzv. Dugom ratu (1591./93. - 1606.). Nakon rata imao je kraljevu podršku te je Matija II. godine 1609. naredio da se od Lucijana ne smiju zahtijevati carina i druge pristojbe kada vozi robu za opskrbu vojske u Vojnoj krajini. Osim u trgovinu, poslovanje je usmjeravao i u druge djelatnosti. Tako je naprimjer 1617., zajedno s gradečkim senatorom i sucem Matijom Posarellom, od Tome Erdődija unajmio na šest godina rudnik bakra kraj Samobora. ${ }^{55}$

Ovdje treba istaknuti i ulogu obitelji Zrinskih, koja je na zagrebačkom području imala svoje trgovine. Petar Zrinski posjedovao je i gostionicu u podgrađu, gdje je prodavao vlastito vino. Općina zagrebačkog Gradeca u više je navrata prosvjedovala protiv prodaje vina Zrinskog i protiv dvojice domaćih trgovaca

\footnotetext{
BUDAK, Društveni i privredni razvoj Križevaca do sredine 19. stoljeća, $42-44$.

53 HSS, knj. 5, 36-37, 56.

54 BUNTAK, Povijest Zagreba, 419-420.

55 PSZ, knj. 17, 378-380; KARAMAN, Zagrebački trgovci u 17. i 18. stoljeću, 257; HERKOV, Povijest zagrebačke trgovine, 51 .
} 
koji su u svojim trgovinama prodavali robu obitelji Zrinski. Zrinski su i u zagrebačkoj Ilici imali još jednu trgovinu gdje su prodavali metalne proizvode sa svojih posjeda. Iz te je drvene kuće 1670. odnesena roba u vrijednosti 1.400 dukata. ${ }^{56}$ Zrinski za svoje trgovine nisu plaćali porez i druge gradske terete. Supruga Petra Zrinskog, Katarina, u Zagrebu je, osim gostionice, imala i trgovinu prekomorske robe. Zrinski su u Zagrebu trgovali sicilijanskom solju na temelju povlastice koju im je 1668. dao kralj Leopold I. za trgovanje prekomorskom robom po cijeloj Hrvatskoj a da pri tome ne plaćaju nikakve daće. ${ }^{57}$

U kaptolsko-biskupskom Zagrebu dolazi do sve veće koncentracije trgovačkog kapitala, posebice krajem 17. stoljeća. Pojavljuje se sve više stranih trgovaca, Štajeraca, Kranjaca i drugih. Oni isprva osnivaju inozemne trgovačke podružnice koje se s vremenom osamostaljuju. U drugoj polovici 17. stoljeća važnu ulogu imalo je nekoliko "stranih" trgovaca kao što su Jesephus Hyroldi (oko 1660.), odnosno Blasius Schnedic ili Shneditz (1670-ih godina), ali se posebno istaknuo Hans Leonhard Mülbacher, poznatiji kao knez Lenard. Iako je imao trgovinu i skladište u jugozapadnom dijelu glavnog trga kaptolsko-biskupskog Zagreba (na uglu kaptolskog trga i Dolca), raspolagao je nekretninama i u zagrebačkom Gradecu. On je počeo poslovati kao pomoćnik trgovca Schnedica, a nakon osamostaljenja 1684. bavio se opskrbom plemićkih i imućnijih građanskih obitelji manufakturnom, odnosno kolonijalnom robom te novčanim poslovima. Za povećanje imetka iskoristio je tzv. Veliki bečki rat (1683. - 1699.). Knez Lenard uključio se u obnašanje javnih dužnosti, primjerice pomoćnika kraljevskog blagajnika Jurja Plemića. ${ }^{58}$

Od varaždinskih trgovaca vrijedi istaknuti Vinka Pergera, ${ }^{59}$ koji je, prema procjenama Mirka Androića, imao kapital u vrijednosti od 81.553 forinte, za koje je krajem 16. i početkom 17. stoljeća u Varaždinu mogao kupiti 551 kuću. ${ }^{60}$ U knjigu varaždinskih građana Vinko Perger bio je upisan 23. veljače 1596., a tom je prigodom uplatio jednu zlatnu forintu i dva talira. ${ }^{61}$ Već 23 . siječnja 1597. Perger

\footnotetext{
56 BUNTAK, Povijest Zagreba, 293, 414.

Historija naroda Jugoslavije, Zagreb, 1959., 714, 716.

58 Josip MATASOVIĆ, Knez Lenard kaptolma zagrebačkoga kramar, Narodna starina, sv. 28, 99-114; sv. 29, 169-204, Zagreb, 1932.; isto, sv. 32, 187-252, Zagreb, 1933.; isto, sv. 33, 15-32; sv. 34, 125-138, Zagreb 1934.; isto, sv. 35, Zagreb, 1935., 59-54.

Državni arhiv Varaždin (DAV) u fondu Poglavarstvo slobodnog i kraljevskog grada Varaždina (PSKGV) postoji niz dokumenata o Pergerovom poslovanju koji se čuvju u Radikalni arhiv, XLVI-737/ G, H, I, J, K, L, M, N, O, P, R, S, T, U, V, W, X, Y, Z.

60 Mirko ANDROIĆ, Varaždinski trgovac Vinko Perger, Kaj, 10, Zagreb, 1968., 63-64.

61 Povijesni spomenici grada Varaždina, 2, Varaždin: Državni arhiv Varaždin, 1991., 356.
} 
za 148 ugarskih forinti kupuje kuću od varaždinskog građanina Stjepana Silića. Tom prilikom saznajemo da je Perger bio Sambarov zet, a supruga mu se zvala Ana. ${ }^{62}$

Perger se 1596. i 1597. spominje u Beču s računima kod trgovačke tvrtke PaarSchaller-Wildbauer te kod trgovca Georgea Feuphera. Perger je u razdoblju 1598. - 1600. godine tekstilnu robu u Beču preuzimao od Niclasa i Paullusa Rottengatera te Martina Parmetera. I 1602. trguje u Beču kod Martina Parmetera te s tvrtkom Hans Puechner i Georg Kirch, koja je sjedište imala kraj Požuna. U Hrvatskoj je odjećom, obućom i oružjem kao i plaćom uzdržavao postrojbu kapetana Baltazara Vragovića. Postoji podatak da je Juraj Pethô de Gerse, uime dijela založenog posjeda Bela, dugovao Pergeru 1.000 rajnskih forinti, pa je ban Toma Erdődy naložio plemićkom sucu Varaždinske županije da Jurja Pethő de Gerse opomene da isplati 1.000 rajnskih forinti ili će Perger taj dio posjeda na ime duga moći prepustiti nekome drugome. ${ }^{63}$

Zapovjednik Slavonske krajine Sigismund Herberstein je od Pergera zatražio da doseljenom vlaškom stanovništvu dade na kredit materijal za odjeću. Herberstein je u jesen 1603. imenovan za člana Dvorskog ratnog vijeća u Grazu. On je početkom 1604. kod štajerskih staleža posredovao da se Pergeru (Bergeru) plati 344 forinta koje je vlaško stanovništvo bilo dužno od dobivanja kredita kojim su nabavili materijal za izradu odjeće. ${ }^{64}$

Godine 1605. uspostavio je trgovačke veze s veletrgovcem tekstila Joakimom Kopenkom iz Jihlave, a o njihovu trgovačkom odnosu postoji osam računa iz perioda od 17. rujna 1605. i 30. rujna 1609. Računi su izdavani u Jihlavi, Linzu, Freistadtu i Beču. Obuhvaćeno je 770 jedinica sukna u ukupnoj vrijednosti 10.813,20 forinti. ${ }^{65}$ Perger sukno nije naručivao samo za sebe već i za još neke trgovce, kao primjerice za Crostofora Luenfeldera iz Radkesburga, Pavla Županiča iz Celja, Matiju Gonana iz Varaždina i Petra Berzeskog iz Križevaca. ${ }^{66}$

Povijesni spomenici grada Varaždina, 3, Varaždin: Državni arhiv Varaždin, 1992., 104, 259.

Mirko ANDROIĆ, Stari putovi tekstila u svijetu i u nas, Textil import-export Zagreb 1952-1977, Varaždin, 1977., 37-38.

Aleksa IVIĆ, Migracije Srba u Slavoniju tokom 16., 17. i 18. stoleća, Naselja i poreklo stanovništva po arhivskim dokumentima, knj. 21, Srpski etnografski zbornik, knj. 36, Subotica, 1926., 23.

DAV, PSKGV, RA, XLVI-737/ G, H, I, J, K, L, N, R; Mirko ANDROIĆ u radu „Stari putovi tekstila u svijetu i u nas" na str. 13, 15, 16, 19, 21, 27, 29, 31, 34 i 39 objavljuje faksimile dijela originalnih dokumenata iz Državnog arhiva u Varaždinu koji se odnose na Vinka Pergera, a dio dokumenata obrađuje i Slavko KAPUSTIĆ, Trgovačke veza Vincenca Pergera, trgovca iz Varaždina, s iglavskim trgovcem Joachimom Kopenkhom, Zbornik radova FOI, 5, Varaždin, 1981., 3-20.

DAV, PSKGV, RA, XLVI-737/K, V, M, U; Slavko KAPUSTIĆ, Trgovačke veza Vincenca Pergera, trgovca iz Varaždina, s iglavskim trgovcem Joachimom Kopenkhom, 7. 
Nikola Istvánffy kao zamjenik ugarskog palatina 1608. zahtijevao je da pred varaždinskim sucem daju svjedočanstva u korist Pergera, čini se, zbog dobivanja plemićkog statusa. ${ }^{67}$ Vinko Perger, civis civitatis Varasdiensis, 1609. na zasjedanju Hrvatsko-slavonskog sabora, nakon davanja uobičajene prisege, primljen je za plemića Kraljevine ${ }^{68}$ Kralj Matija II. Habsburgovac 1610. godine primio je Vinka Pergera u Beču te mu dao nalog za poduzimanje odgovarajućih mjera kako bi zagrebački trgovac Lucijan Calcinelli podmirio dugove prema Pergeru. ${ }^{69}$

Vinku Pergeru 19. ožujka 1609. osmanski trgovac Hagy Memmi pisao je pismo u kojem mu je javio da paša inzistira na proširenju njihove međusobne trgovine. Očito je ta trgovina bila postojala prije te godine. Alajbegov sin donio je 1609. godine Pergeru 400 zlatnih dukata i zlato u vrijednosti od 200 dukata za „neku tešku robu“ (u pismu se naglašava da se ne smije znati koja je to roba), vjerojatno oružje, koju je kao „kamenje za reguliranje Drave“ Perger trebao dopremiti do Drnja, a Osmanlije su je trebali otpremiti niz Dravu dalje prema isto$\mathrm{ku}$. Sve se radilo u sporazumu s pašom, a u trgovačkim poslovima morali su se bojati jedino hajduka. ${ }^{70}$

U srpnju 1616. plemić Joakim Kopenko, zapisan kao Topenko civis et negociator civitas Iglawiensis, daje izjavu vezanu uz dug pokojnog Vinka Pergera. ${ }^{71}$ Čini se da je Pergerovo poslovanje završilo bankrotom, pa je $u$ Varaždinu proveden niz prodaja njegove imovine i ovrha ${ }^{72}$ nakon smrti. Smrt se morala dogoditi prije 3. lipnja 1616. jer se tada spominje njegova udovica Ana rođena Sambar, i to $u$ prosvjedu koji su zbog novčanog duga protiv nje pokrenuli varaždinski klobučari Jakob Fierczig, Juraj Marencz i Mihael Kobilić, a 1618., uz Jakoba Fiercziga i Jurja Marencza, u vezi s Pergerovim dugom spominje se i Nikola Pipan. ${ }^{73} \mathrm{Na}$ činjenicu da je Varaždin bio atraktivan nizu stranih trgovaca, ukazuje niz podataka, kao naprimjer kada su početkom 17. stoljeća tamo djelovali bečki trgovci, primjerice članovi obitelji Catio, od koje se 1616. spominje Alecander, a 1617. Melchior i Hyeronym. ${ }^{74}$ Moguće je da je iz iste obitelji bio trgovac Gabriel Caccia iz Ptuja. On je zajedno s bratom Georgom i partnerom Franzom Furlanom 1645.

\footnotetext{
67 ANDROIĆ, Stari putovi tekstila u svijetu i u nas, 37.

70 DAV; AGV, Radikalni arhiv, II, br. 958; ANDROIĆ, Varaždinski trgovac Vinko Perger, 63; isti, Prilozi poznavanju društvenih i gospodarskih prilika grada Varaždina u 18. stoljeću, u: Varaždin u XVIII stoljeću i političko-kameralni studij, Zagreb - Varaždin, 1972., 17, 67-68.

74 ZPV 4, 186, 213, 217.
} 
otvorio trgovinu-kantinu u Varaždinu jer su se vojnici tužili da za svaku sitnicu moraju ići u Ptuj. U toj su se trgovini-kantini opskrbljivali ne samo vojnici iz varaždinske utvrde, kojima je Caccia mogao odobravati jednogodišnji kredit u visini četiri mjesečne plaće, nego i civilno stanovništvo. Caccia je uložio prigovor da su mu troškovi za prijevoz robe konvojem previsoki, a k tome mora plaćati znatnu maltarinu, te je izrazio želju da ga se oslobodi tridesetine. Ta kantina-trgovina u Varaždinu kasnije će postati predmetom mnogih sporova, npr. vojnici su optuživali Cacciu da ih vara, a on je nalazio izgovor u svojem partneru Furlanu. $^{75}$

Zapovjednik Slavonske vojne krajine Schwarzenberg žalio se 1646. da su vojnici bili sasvim bez financijskih sredstava, pa su kod trgovaca morali uzimati robu na kredit. Zapovjednik je tvrdio kako s otvaranjem trgovine-kantine nije postignuta svrha jer su vojnici skupo plaćali lošu robu, a na dugove su im obračunavali lihvarske kamate. Zato je vojska provaljivala na osmanski teritorij i pljačkala, što je moglo ugroziti mir s Osmanskim Carstvom. Caccia 1647. šalje staležima u Graz informaciju da njegova trgovina-kantina u Varaždinu dobro prolazi i kod vojnika i kod varaždinskih građana, no robu nije mogao prodavati jeftinije zbog velikog poreza, ali i zbog razlike u mjerama jer je, prema njegovim riječima, lakat (kao mjera) u Vojnoj krajini bio dulji nego u Ptuju, pa se na tome gubilo. Caccia je tvrdio da su vojnici bili zadovoljni njegovom trgovinom-kantinom, ali je i smatrao kako su časnici bili protiv njega jer im nije htio davati postotak. Caccia je imao mišljenje kako njegova roba nije bila ni loša ni odležana, no usprkos tome vojni pisari nisu vojnicima davali zadužnice te oni nisu mogli kupovati. Vojnici su priznali da Caccia ima svježu robu i da su u Varaždinu na ratnom terenu morali kupovati jer nemaju ni najnužnije za jelo. Caccia je $\mathrm{k}$ tome tražio da mu staleži isplate plaću za četiri mjeseca za vojnike jer da ih je on iz svoje trgovine-kantine isplatio robom. ${ }^{76}$

Križevački kapetan i zamjenik zapovjednika Varaždinskoga generalata Ivan Jakob Galler opravdavao se pred štajerskim staležima kako su ga nedobronamjerni ljudi oklevetali da trguje suknom po križevačkom kraju te da je zato protiv Caccie i njegove trgovine-kantine u Varaždinu. Staleži u Grazu saznali su 1649. da je trgovac iz Ptuja Gabriel Caccia sklopio ugovor s Nikolom Zrinskim iz Čakovca kako bi pšenicu transportirao u Mletačku Republiku. Staleži to nisu tolerirali i tvrdili su kako je zadatak Caccie brinuti se za provijant u Vojnoj kra-

\footnotetext{
75 Steiermärkischen Landesarchiv (dalje: STLA), Graz, Laa. A. Antiquum XIV - Militaria, Sch. 176; ILIJANIĆ, Nekoliko podataka o vezama Ptuja i Varaždina u 16. i 17. stoljeću, 291.

76 STLA, Laa. A. Antiquum XIV - Militaria, Sch. 177, 179; ILIJANIĆ, Nekoliko podataka o vezama Ptuja i Varaždina u 16. i 17. stoljeću, 291.
} 
jini. Na to se Caccia ispričavao i izgovarao na Nikolu Zrinskog, čiji su trgovački predstavnici prodavali u Ptuju, a kako im je cijena bila preniska, oni su tu robu vratili natrag u Čakovec. Vjerojatno ipak poslovi Caccie nisu bili potpuno čisti jer je Dvorsko ratno vijeće pisalo staležima u Grazu da bi Caccii trebalo zabraniti trgovinu koja je prelazila zadane okvire. Naime Caccia je za izdano sukno vojnicima od fiska dobivao novac, pa je već na toj činjenici zarađivao te je upozoreno - ako se ubuduće ne bude držao reda - da će se njegovo trgovanje smatrati krijumčarenjem, da će on osobno biti kažnjen, a da će mu se roba oduzeti. Možemo pretpostaviti da su i križevački kapetan Galler i Zrinski iz poslovanja s Cacciom gledali izvlačenje vlastite koristi. ${ }^{77}$

Iako su vojne vlasti 1648. donijele odluku o ukidanju Cacciine trgovine-kantine, Caccia je ostao i dalje djelovati u Varaždinu kao trgovac jer ga se spominje 1649., kada mu je štajerska blagajna trebala isplatiti 7.813 forinti za robu koju je izdao varaždinskoj vojnojkrajiškoj posadi na zadužnice. Taj mu je iznos isplaćen iduće, 1650. godine. Staleži su zapravo ovisili o aktivnosti Caccie jer sami nisu mogli redovito izvršavati novčane obveze prema vojnicima Vojne krajine te su, zbog stalnih materijalnih briga, morali popuštati. Godine 1650. staleži su pisali zapovjedniku Varaždinskoga generalata Walteru Lesliu kako su oni Caccii dozvolili otvaranje trgovine $u$ Varaždinu, iako se nisu slagali s njegovim špekulantskim načinom poslovanja. Usprkos tome naredili su Lesliju da nagovara vojnike da uzimaju robu iz Cacciine trgovine jer već neko vrijeme nisu dobili plaću, što govori da je ta trgovina i dalje djelovala, odnosno da ranija odluka o ukidanju trgovine-kantine možda nije odmah bila provedena u djelo. ${ }^{78}$

Očito se u trgovini u pograničnim utvrdama razvila korupcija, a čini se da su, osim Caccie, na vojnicima zarađivali i časnici i vojni pisar. To ukazuje na problem organizacije vojne trgovine u Varaždinu. Moguće je da je Caccia ostao u Varaždinu i nakon zatvaranja trgovine-kantine. ${ }^{79}$ No čini se da su štajerski staleži najveći dio trgovačkog poslovanja s utvrdama Slavonske vojne krajine povjerili tom trgovcu iz Ptuja.

U trgovini s Vojnoj krajinom sudjelovalo je i više domaćih trgovaca. Bartol Presečki (Bersetski, Persecko, Persetscho, Berzetscho) preko Italije i Koruške dopremao je talijansko vino i ulje. $S$ vojskom su trgovali i trgovci iz obitelji Gonan, kao naprimjer 1643. godine, kada su prigodom nabave žita za utvrdu u Križev-

\footnotetext{
77 STLA, Laa. A. Antiquum XIV - Militaria, Sch. 183; ILIJANIĆ, Nekoliko podataka o vezama Ptuja i Varaždina u 16. i 17. stoljeću, 291-292.

78 STLA, Laa. A. Antiquum XIV - Militaria, Sch. 180-189; KAPUSTIĆ, Nekoliko riječi o organizaciji trgovine s graničarima u Varaždinu 17. stoljeća, 400; ILIJANIĆ, Nekoliko podataka o vezama Ptuja i Varaždina u 16. i 17. stoljeću, 292. 
cima imali na terenu svoje dobavljače. Moguće je da je u trgovini s vojskom u utvrdama Slavonske vojne krajine poslovao i varaždinski trgovac Kristofor Neustätter, koji je 1653. javljao staležima u Graz da je u njegovoj trgovini ostalo sukno koje će pokušati prodati vojnicima u utvrdi Koprivnica. ${ }^{80}$ Trgovina s graničarima pripomogla je činjenici da su Varaždinci mogli u svojem gradu kupiti istu takvu robu kakva se u to vrijeme prodavala i u ostalim srednjoeuropskim gradovima.

U ranom novom vijeku veliku važnost imala je trgovina solju. U 17. stoljeću Varaždin se opskrbljivao osmanskom soli iz Ugarske. Ta se sol nabavljala iz Kaniže. No Unutarnjoaustrijska dvorska komora u Grazu bila je zainteresirana da se utvrde Varaždinskoga generalata (Slavonske vojne krajine), a time i Varaždin, opskrbljuju iz solane Aussee, koja je bila u posjedu štajerskih staleža kojima je bilo u cilju prodati što više robe u pograničnom prostoru uz Dravu. ${ }^{81}$ Glavno skladište za distribuciju soli postao je Varaždin. Iz njega se sol dovozila u Koprivnicu, Međimurje i na čitav pogranični prostor. Krajiški zapovjednici u Varaždinu, Koprivnici i Đurđevcu solju su se opskrbljivali i od osmanskih trgovaca. Zbog toga su štajerski staleži ishodili vladarevu odluku kojom je zapovjednicima u tim mjestima zabranio kupovanje soli od Osmanlija. ${ }^{82}$

Za opskrbu solju Varaždina i utvrda Varaždinskoga generalata trebao se pobrinuti ptujski građanin Octavio Bonicceli kao Salzversilberer u Varaždinu i fiskalni administrator u Čakovcu Gregur Pavešić, koji je na to pristao pod uvjetom da se zabrani trošenje soli iz Osmanskog Carstva kojom su trgovali varaždinski trgovci. Bonicceli je sumnjao da će područje koje je trebao opskrbljivati prihvatiti sol iz Aussea, što se vidi iz jednog od pisama Dvorskoj komori iz 1675. godine. Iduće, 1676., godine zabranjen je uvoz soli iz Osmanskog Carstva, a uvedena je i uvozna carina koju su trebali ubirati zapovjednici u Koprivnici i Đurđevcu. Pavešić je trebao sol dopremati rijekom Murom, a Bonicceli se trebao brinuti za njezino skladištenje u Varaždinu. Tada se vodila briga da se sol iz Aussea, koja je bila čišća od osmanske, uvodi postupno kako u narodu ne bi došlo do bune. Veličina pakovanja između soli iz Aussea i osmanske nije se razlikovala. Varaždinski trgovci na čelu s bogatim Danijelom Praunspergerom (Praunsbergerom) digli su bunu protiv Boniccelija te su ga tužili da protuzakonito uvodi novotarije u trgovinu u Hrvatsko-Slavonskom Kraljevstvu tražeći da se Bonicceli udalji iz

\footnotetext{
$\overline{80}$ STLA, Laa. A. Antiquum XIV - Militaria, Sch. 174, 194; KAPUSTIĆ, Nekoliko riječi o organizaciji trgovine s graničarima u Varaždinu 17. stoljeća, 402.

81 Slavko KAPUSTIĆ, O borbi za tržište soli u Varaždinu 17. stoljeća, Zbornik radova Fakulteta organizacije i informatike u Varaždin,u 5, Varaždin, 1981., 22. 
Varaždina. Protiv njega je bilo upotrijebljeno i oružje. Građani Varaždina žalili su se Ugarskoj komori, koja je zatražila obustavu opskrbe solju iz Aussea. Dvorska komora u Grazu neuspješno je pokušala urediti spor u svoju korist. Nakraju je, zbog velike vlage, preostala sol iz Aussea propadala, pa je Bonicceli od Dvorske komore tražio dozvolu da sol proda drugdje. Moguće je da se sve to događalo zbog toga što je trgovcima iz Varaždina odgovarala opskrba solju iz Osmanskog Carstva preko koje su mogli ostvarivati veću dobit. Očito je buna protiv Boniccelija predstavljala borbu za zaštitu vlastitih trgovačkih interesa. ${ }^{83}$

Zanimljivo je da je Octavio Bonicceli još 1673. imao kuću u Varaždinu. Godine 1675. Bonicceli je, zajedno sa suprugom Elizabetom, kupio u unutrašnjem dijelu Varaždina zidanu kuću od Franje Patačića za 800 rajnskih forinti, jedna kola i pola bale nizozemskog sukna. ${ }^{84}$ Moguće je da je tu kuću kupio jer je u njoj planirao organizirati skladište soli i trgovinu. ${ }^{85}$

U Varaždinu su postavljali i prepreke stranim trgovcima, primjerice kada je 1676. gradački trgovac Schefller u Varaždinu nastojao otvoriti svoju filijalu. ${ }^{86}$ Gradačke trgovce trebalo bi podrobnije obraditi u zasebnom istraživanju.

Na pojačanu trgovačku aktivnost u Koprivnici početkom 17. stoljeća ukazuje doseljavanje mletačkih trgovaca. Radilo se o Leonardu Gofu, sinu Petra de Pasariisa, koji se u Koprivnicu doselio sa suprugom Angelom iz Tolmezza (sjeverno od Udina) u Mletačkoj Republici 1602. godine ${ }^{87}$ te trgovcu iz istoga mletačkoga grada Antunu Toniuttiju, koji se u Koprivnicu doselio nakon 21. kolovoza $1608 .{ }^{88}$ Njima treba pribrojiti obitelj Gonan, čiji se pripadnici spominju kao gradski suci u Koprivnici (1652.) i Križevcima $\left(1617 .^{89}\right.$ i 1647.90). Oni su bili Talijani ili Furlani, najvjerojatnije trgovci, koji su se u te krajeve doselili u doba gospodarske obnove početkom 17. stoljeća preuzimajući ubrzo vodeće uloge u dvama pograničnim

83 STLA, Innerösterreichischen Hofkammer, god. 1675., 1676.; Slavko KAPUSTIĆ, O borbi za tržište soli u Varaždinu 17. stoljeća, 22-24; ILIJANIĆ, Nekoliko podataka o vezama Ptuja i Varaždina u 16. i 17. stoljeću, 292.

Zapisnici poglavarstva grada Varaždina, 8, Varaždin, 2000., 118, 227.

KAPUSTIĆ, O borbi za tržište soli u Varaždinu 17. stoljeća, 24.

Mirko ANDROIĆ, Neke značajke razvoja Varaždina u XVIII. stoljeću, Varaždinski zbornik, Varaždin, 1983., 212. Hrvatski državni arhiv (HDA), Grad Koprivnica (HDA, GK), kut. 5, br. 11.

88 HDA, GK, kut. 6, br. 1.

Emilije LASZOWSKI, Deset listina za povjest grada Križevaca od XV. do XVII. vijeka, Vjesnik zemaljskog arkiva, god. 4, Zagreb, 1902., str. 264. 
gradovima.$^{91}$ Koprivnica je u to vrijeme bila zanimljiva i njemačkim trgovcima, pa se tako 1608. u taj grad doselio trgovac tekstilom Martin Desenmayer. ${ }^{92}$

Koprivnička je trgovina, nakon kratkog zamaha početkom 17. stoljeća, stagnirala sve do kraja 17. stoljeća. ${ }^{93}$ Znakovito je da su oba uspona koprivničke trgovine vezana uz dva rata - „Dugi rat“ (1591.-93., 1606.) i „Veliki bečki rat“" (1683. - 1699.). „Domaći“ se trgovci u međuvremenu rijetko spominju, kao primjerice „dernianszki kramar Ivan“ 1677. godine. ${ }^{94}$

Iz historiografije je poznato da je u Varaždinu djelovao ceh trgovaca koji je svoja pravila dobio 1629. godine. Kako su ta pravila izgorjela u požaru 1665. godine, novi je statut kralj Leopold potvrdio 1675 . godine. ${ }^{95}$ Grad je bio privlačan strancima, a u razdoblju 1667. - 1676. godine trajao je spor koji je izbio zbog toga što su domaći trgovci unutar ceha trgovaca pokušali zabraniti primanje stranaca $u$ to udruženje. ${ }^{96}$ Osim toga, dio trgovine regulirao je novi statut grada Varaždina iz 1699. godine. ${ }^{97}$ Po uzoru na varaždinske trgovce, i gradečki su se trgovci udružili u poseban ceh 1698. godine. ${ }^{98}$ No gradečki su obrtnički cehovi prosvjedovali zbog osnutka ceha trgovaca. Gradska je uprava, u kojoj su velik utjecaj imali obrtnici, djelomično uvažila prosvjed. Magistrat je donio odredbu da trgovci moraju u svako doba imati dovoljnu količinu zaliha različite robe kako građani ne bi mogli iznositi prigovore o eventualnim nestašicama. Ako domaći trgovci nisu imali neku robu, bilo je dozvoljeno da je uvezu strani trgovci i slobodno prodaju. ${ }^{99}$

\section{Tržišta i njihova geografija}

Zagreb je od početka 17. stoljeća imao središnju ulogu pri unutrašnjoj razmjeni dobara unutar Hrvatsko-Slavonskoga Kraljevstva, što se može vidjeti iz istraživanja trgovačkih prilika u zagrebačkim naseljima provedenog 1602., prigodom kojega je anketirano pet stotina svjedoka s prostora od Varaždina i Kri-

\footnotetext{
91 BUDAK, Pogranična gradska naselja sjeverne Hrvatske u 17. stoljeću, 32.

92 DAV, Arhiv grada Varaždina, spis br. 737, od 28. kolovoza 1608.

93 PETRIĆ, Koprivnica u 17. stoljeću, 174-180.

94 DAV, Zapisnici poglavarstva grada Koprivnice (ZPGK), spis od 29. srpnja 1677.; Karmen LEVANIĆ, Zapisnici poglavarstva grada Koprivnice 1639.-1700., knj. 1, Samobor: Meridijani, 2006., 174.

95 HERKOV, Povijest zagrebačke trgovine, 128.

96 Ivy LENTIĆ-KUGLI, Varaždin, Zagreb: Društvo povjesničara umjetnosti Hrvatske, 1977, 47.

97 Statut grada Varaždina, Varaždin, 2001., 59-69.

98 Rudolf HORVAT, Prošlost grada Zagreba, Zagreb: August Cesarec, 1992., 367.

99

HERKOV, Povijest zagrebačke trgovine, 132-135.
} 
ževaca pa do Turopolja i Samobora, što može ukazivati na geografski obuhvat zagrebačke trgovine. ${ }^{100}$

Bila je snažna i trgovačka povezanost s unutarnjoaustrijskim (slovenskim) prostorom i za to ima dosta primjera. Naprimjer za Varaždin smo ranije iznijeli niz primjera, a njima treba dodati i da će se trgovina prema Ptuju održavati i krajem 17. stoljeća; ${ }^{101}$ u Varaždinu su u drugoj polovici 17. stoljeća djelovale i podružnice ljubljanskih trgovaca, ${ }_{102}^{102}$ poput Caharija Waldtreicha, u čijem je ostavinskom inventaru zapisana poslovna knjiga trgovinskog društva Antona i Baltazara Waldtreicha u Varaždinu iz perioda 1670. - 1674. ${ }^{103}$; nažalost, ta se knjiga nije sačuvala do našeg vremena.

Ranije spomenuti varaždinski trgovac Vinke Perger opsegom svoje trgovine obuhvaćao je razne dijelove Habsburške Monarhije i rubno je dopirao sve do Engleske i Osmanskog Carstva. Pergerova trgovina, osim do brojnih hrvatskih i slovenskih gradova, dolazila je do Nürnberga, Jihlave (Ihlava, Iglau), Graza, Beča, Linza itd. ${ }^{104}$

Osim nekoliko detalja poput onoga da je Perger trgovao s osmanskim trgovcem Memmijem ${ }^{105}$ ili informacija o trgovini solju s pograničnim dijelom Osmanskog Carstva, nema mnogo podataka o drugim oblicima prekogranične trgovine, no ona se očito odvijala. Primjerice na Wincklerovoj karti iz 1639. godine označeno je pet putova iz hrvatskog prostora prema Osmanskom Carstvu, koji su mogli koristiti i za prekograničnu trgovinu trgovaca iz Varaždina, Koprivnice, Križevaca i Zagreba. To su bili putovi: Petrinja - Kostajnica, Čazma Kutina, Severin - Pakrac, Severin - Stupčanica i Đurđevac - Virovitica. ${ }^{106}$ Osim toga postoji podatak da su varaždinski trgovci Kristofor Neustetter i Bartolomej Andruiz izvozili med u Osmansko Carstvo. ${ }^{107}$

Zagreb je, nakon kriznog perioda krajem 16. stoljeća, raznim olakšicama nastojao privući ne samo trgovce nego i obrtnike kako bi se oživila gospodarska

\footnotetext{
$\overline{100}$ KARAMAN, Zagrebački trgovci u 17. i 18. stoljeću, 254.

101 DAV, Arhiv grada Varaždina, Radikalni arhiv, 958 XLVII-751.

102 Arhiv Republike Slovenije, Zap. inv. št. 328, 329, 330, 334-339, 341-342, 343-347.

103 Vlado VALENČIČ, Ljubljanski trgovec in bankir Caharija Waldtreich (1623-1682), Zgodovinski časopis, 26, Ljubljana, 1972., 321-323.

104 Mirko ANDROIĆ, Varaždinski trgovac Vinko Perger, 63-64.

105 ANDROIĆ, Prilozi poznavanju društvenih i gospodarskih prilika grada Varaždina u 18. stoljeću, 17, 67-68.

106 Hrvatski državni arhiv (HDA), Ujedinjena Bansko-Varaždinsko-Karlovačka generalkomanda, Uvezeni spisi Varaždinskog generalata, 1578-1848.

107 Rudolf HORVAT, Povijest trgovine, obrta i industrije u Hrvatskoj, Zagreb: AGM, Hrvatska gospodarska komora, 1994., 123.
} 
djelatnost. Taj je grad u 17. stoljeću bio zanimljiv stranim trgovcima, odnosno onima koji nisu imali status građana. Za takve je trgovce upravljački sloj slobodnog i kraljevskog grada odredio posebne propise kojima im je ograničeno trgovanje samo u vrijeme sajmova, dok im je druga trgovina bila zabranjena. No, zagrebački statut iz 1609. donekle je ublažio odnos prema stranim trgovcima. Iako je sadržavao odredbu po kojoj su strani trgovci koji nisu bili stalno nastanjeni u slobodnom i kraljevskom gradu Zagrebu ili koji tamo nisu imali kuće morali biti otjerani uz oduzimanje trećine robe, nudio je mogućnost da se to otkloni ako ti trgovci $\mathrm{u}$ roku od pola godine ne kupe kuću ili se ne nastane $\mathrm{u}$ Zagrebu te upišu među građane..$^{108}$ Dana 4 . veljače 1676. donesena je odredba po kojoj oni strani trgovci koji su u Zagrebu imali poslovnice u njima nisu smjeli prodavati robu izvan vremena sajmova. U slučaju kršenja odredbe, trebala im je biti oduzeta roba koju su posjedovali. Izvan sajmenog vremena smjeli su trgovati samo oni trgovci koji su imali status građana. ${ }^{109}$ Restriktivna politika vodećeg sloja slobodnog i kraljevskog grada Zagreba (Gradeca) usmjerila je strane trgovce prema kaptolsko-biskupskom Zagrebu, koji ih je slobodnije prihvaćao. Zbog toga je dolazilo do sporova, pa i nasilnog odvlačenja trgovaca, kao primjerice 1603., kada su građani slobodnog i kraljevskog grada na cesti napali kaptolskog trgovca talijanskog podrijetla Ivana Toscana odnijevši mu silom sve stvari na gradečki trg. ${ }^{110}$

O jačanju veza s ugarskim područjima koji su vraćeni pod habsburšku vlast svjedoči nazočnost zagrebačkog trgovca Martina Görösa u Sigetu 1695. ${ }^{111} \mathrm{Na}$ drugoj strani na trgovačke veze s Osmanskim Carstvom upućuje primanje bosanskog trgovca i krznara Petra Franića iz Sarajeva za člana zagrebačke gradečke općine $1692 .{ }^{112}$

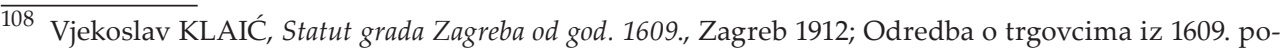
stoji i u hrvatskokajkavskoj verziji statuta iz 1629. godine: „kramare zvanskeh narodov, tepce, stanovita mesta ni hiže nemajuče, niti purgari buduči, koji listor s ciganijami na ščap varaški prihajaju, z varaši arti zvrgu, trejti del blaga za varaš zavjemši, akko bi do pol leta ali hiž ali kakova funduša hižnog ne kupili i ako bi se med purgare ne spravili, ter takvem izvrženoem kramarom klatešom da im se v veke ima prepovedati, da pod zgublenje vse svoje marhe, kotere ako bi zadovoljne namali, pod otkup glavni, to je to pod stro dukat biršaga, nemaju v varoš prijeti." Olga ŠOJAT, Hrvatski kajkavski pisci, Zagreb, 1977., 262.

Zlatko HERKOV, Statut grada Zagreba od god. 1732., Zagreb, 1952., 58; HERKOV, Povijest zagrebačke trgovine, 13-14.

110 KARAMAN, Zagrebački trgovci u 17. i 18. stoljeću, 252-254.

111 Slavko GAVRILOVIĆ, Ivan JAKŠIĆ, Sreta PECINJAČKI, Građa o balkanskim trgovcima u Ugarskoj XVIII veka, knj. 1 - carinarnice i kontumaci, Beograd: SANU, 1985., 224.

112 PSZ, knj. 18, 313; KARAMAN, Zagrebački trgovci u 17. i 18. stoljeću, 60. 
Potpisivanjem Karlovačkog mira 1699. godine došlo je do prelaska većeg dijela srednjeg Podunavlja pod vlast Habsburgovaca. ${ }^{113}$ Nakon što je Habsburška Monarhija zavladala plodnim podunavskim područjem, austrijska vanjska trgovina okrenula se prema zapadu, gdje je vladao interes za njezine poljoprivredne proizvode i industrijske sirovine, što je rezultiralo praktičnim povezivanjem Habsburške Monarhije sa svjetskim tržištem stvorenim nakon velikih geografskih otkrića. Sjevernojadranske luke trebale su postati glavna ulazno-izlazna vrata Habsburške Monarhije prema zapadnim tržištima. Zbog toga su Habsburgovcima izlaz na Jadransko more i slobodna plovidba bili među prioritetima. Istodobno su provođeni napori kako bi se što veće količine robe s jugoistočnih područja preuzetih od osmanske vlasti usmjerile prema sjevernojadranskim lukama. ${ }^{114}$ Prije potpisivanja mirovnog ugovora 1699. u Hrvatskoj je tranzitna trgovina bila u opasnosti zbog blizine granice s Osmanskim Carstvom. To je razlog što je najveći dio prometa iz zapadnih dijelova Ugarske i susjednih austrijskih zemalja bio usmjeren preko slovenskog etničkog prostora prema Rijeci, Trstu ili Mletačkoj Republici. Usprkos tome i neki dijelovi Hrvatske pod vlašću bana bili su uključeni u trgovinu - primjerice Varaždin, koji je konkurirao Ptuju u Štajerskoj, Koprivnica, luka Bakar koja je služila za trgovinsku djelatnost obitelji Zrinski i dr. ${ }^{115}$

Izvan užih lokalnih okvira trgovačka se razmjena u Hrvatskoj pod vlašću bana krajem 17. stoljeća uglavnom temeljila na izvozu poljoprivrednih, stočarskih i u vrlo maloj mjeri obrtničkih, odnosno manufakturnih proizvoda. Istodobno su se uvozili tekstil, kolonijalna roba te luksuzni proizvodi i sl. Trgovačkim je poduzetnicima za razvijanje uspješne poslovne aktivnosti trebala posrednička djelatnost u robnom prometu s područjima koja su se nalazila izvan Habsburške Monarhije. Osnovicu takvom trgovačkom poduzetništvu tih prostora pružao je njihov povoljni ekonomski položaj u jugoistočnoj Europi, tim više što su predstavljali mjesto susreta pomorskih, cestovnih i riječnih putova koji su povezivali dijelove jugoistočne Europe, Podunavlja te predalpskog i alpskog prostora s Jadranskim i Sredozemnim morem. Ne treba smetnuti s uma kako je pri tome posebno važna bila merkantilistička politika Habsburgovaca. ${ }^{116}$

113 Enes PELIDIJA, Bosanski ejalet od Karlovačkog do Požarevačkog mira 1699. - 1718, Sarajevo: Veselin Masleša, 1989., 237-259.

114 Nikola PETROVIĆ, Plovidba i privreda srednjeg Podunavlja u doba merkantilizma. Izgradnja kanala DunavTisa i napori za povezivanje srednjeg Podunavlja sa Jadranskim morem krajem XVIII veka. Beograd, 1987., 26.

115 PETRIĆ, Koprivnica u 17. stoljeću - okoliš, društvene, demografske i gospodarske promjene u pograničnom gradu; Igor, KARAMAN, Privredni život banske Hrvatske od 1700. do 1850. Zagreb: SNL, 1989., 13.; Josip ADAMČEK, Trgovačke veze sjeverne Hrvatske s primorjem u XVI i XVII stoljeću, Dometi, 10/1977, 77-82.

116 KARAMAN, Privredni život banske Hrvatske od 1700. do 1850, 12-13. 
U trgovačkoj razmjeni s Osmanskim Carstvom u Habsburšku Monarhiju uvoženi su pamuk, vuna, stoka, koža, svila, vosak, maslinovo ulje, južno voće, suha riba, med, duhan, riža, vino, rusko krzno, kava, šećer, šafran, alati itd. Habsburškoj Monarhiji najviše je bilo stalo do pamuka i vune kao sirovina za manufakture te voska i duhana. Bilo je problema s izvozom neke robe iz Osmanskog Carstva jer je Porta povremeno zabranjivala izvoz voska i podizala carine. Izvoz Habsburške Monarhije sastojao se od stakla, drva, željeznih predmeta, bakra, olova, žive, malih količina porculana, lijekova, satova, posuđa, proizvoda od drva itd. Unutar habsburško-osmanske trgovine posebnu važnost zauzimali su prostori Makedonije, Srbije i Bosne, a sve do potkraj 17. stoljeća veliki je dio balkanske trgovine bio u rukama Dubrovčana. $S$ vremenom su taj dio trgovine preuzeli Grci, Cincari, Armenci, Židovi, Albanci i Bošnjaci. „U Makedoniji i Srbiji kao privilegovani sloj javljaju se grčko-cincarski trgovci koji su po tamošnjim gradovima stvorili svoje kolonije, orijentišući se u svojoj trgovini prema Austriji, izvozeći razne proizvode Balkana i Levanta, a naročito pamuk i vunu za austrijsku tekstilnu industriju. ${ }^{\prime 117}$

Nakon potpisivanja Požarevačkog mira pravoslavni trgovci na veliko i malo iz Osmanskog Carstva preplavili su mnoga područja u Habsburškoj Monarhiji, a u njihovim je rukama bila gotovo sva kopnena trgovina između Bliskog istoka i srednje Europe. Ti su trgovci svojim obiteljima, koje su zadržali u osmanskom podaništvu na osmanskom teritoriju, slali zaradu. ${ }^{118}$

Kao primjer obnove trgovačke aktivnosti krajem 17. stoljeća uzmimo Koprivnicu i općenito Križevačku županiju, u kojoj su u zadnjim desetljećima zabilježeni pravoslavni trgovci ${ }^{119}$ podrijetlom s prostora Osmanskog Carstva, poznatiji kao tzv. "grčki“" trgovci. ${ }^{120}$ Čini se da je i koprivnički trgovac Izak Petrović, spomenut 1681., ${ }^{121}$ najvjerojatnije pripadao "grčkim“ trgovcima. Na stvaranje sre-

$\overline{117}$ Marianne von HERZFELD, Zur Orientalhandelspolitik Österreichs unter Maria Theresia in der Zeit von 1740-1771, Wien: Archiv für österreichische Geschichte. Band 108, 1919., 228, 277-281; Slavko GAVRILOVIĆ, Prilog istoriji trgovine i migracije Balkan-Podunavlje XVIII i XIX stoleća, Beograd: SANU, 1969., 11-12, 14-15.

118 Dušan POPOVIĆ, Cincari. Zagreb: MISL, 2007., 86-93.

119 Trajan STOJANOVIĆ, The Conquering Balkan Orthodox Merchant, The Journal of Economic History, vol. 20, no. 2, 1960., 234-313.

120 ZHS 1, Zagreb, 1958., 409; Hrvoje PETRIĆ, Pravoslavni trgovci iz Osmanskog Carstva u Banskoj Hrvatskoj i Varaždinskoj krajini početkom 18. stoljeća, Zbornik Nikše Stančića, Zagreb, 2011., 89-98; Slavko GAVRILOVIĆ, Prilog istoriji trgovine i migracije Balkan-Podunavlje XVIII i XIX stoleća, 73; o pravoslavnoj crkvenoj općini na Gradecu usp. radi komparacije Drago ROKSANDIĆ, Pravoslavna crkvena općina na području Gradeca između patenta o toleranciji 1781. i revolucije 1848/49, Zagrebački Gradec 1242-1850, Zagreb, 1994., 277-292.

121 DAV, AGK, ZPGK 1676-1687, spis od 9. srpnja 1681.; Zapisnici poglavarstva grada Koprivnice 1639.1700., knj. 1, 341, 343; H. PETRIĆ, Koprivnica u 17. stoljeću, str. 167.-168. 
dišta pravoslavnih trgovaca iz Osmanskog Carstva upravo u Koprivnici imala je utjecaj i činjenica blizine jačanja riječnoga prometa na Dravi kao dio važne trgovačke transverzale između jugoistočne Europe i Podunavlja. U susjednim trgovištima Legradu i Drnju nalazile su se riječne luke na Dravi važne za koprivničko gospodarstvo. Luka Legrad imala je dodatno značenje jer se nalazila blizu utoka rijeke Mure u Dravu te je omogućavala trgovinu Murom uzvodno sve do Štajerske. ${ }^{122}$

Pravoslavni trgovci u Koprivnici spominju se 1698. godine, kada je zabilježeno da trguju robom iz Osmanskog Carstva, a gradsko poglavarstvo donijelo je odluku o plaćanju takse: „Radi Gerkov koy z partekom turszkom ovdi pri plamenitom Varassu terse, dokanchasze ovako artikulariter: da oni koyszu do szada pri plemenitom Varasssu bili posztave taxu, toieto za letho lanzko vuzaki po 3 Rheneses, ravno tako y oni koyszu szada k Varassu dosli, vuzaki poszebi po rainiski 1 na meszecz ieden. Koiu taxu polosivsi, szlobodno bude takov szpartekom szvoiom pri plemenitom Varassu sztal, niu prodaval y tersil do jedan meszecz dan, koteri meszecz dan izminuvsi, da bude moral y zpartekom oditi od Varassa, akolibi pak nadalie hotel pri Varassu zrechenom szvoiom partekom osztati, da bude nazopet drugi rainiski posztaviti moral, et sic consequenter. Koysze pako vutom tverdokoren naide, szpartekom szvoiom za plemeniti Varas zapadal bude y ravno tako da akosze koy zmed nyh naide koibi po szobottah mezo iel, da bude 12 rainiskih tulikaise birsagha zapadal y gubil.." ${ }^{\prime 123}$ Prema tome, pravoslavni trgovci koji su dolazili trgovati u Koprivnicu morali su za 1697. platiti porez od 3 rajnska forinta. Dalje su morali plaćati jedan rajnski forint mjesečno. I zapisnici kanonskih vizitacija spominju pravoslavne (trgovce) u Koprivnici, među kojima razlikuje Vlahe od „Grka. Primjerice 1700. godine za njih piše: „Nedavno dođoše stanoviti Vlasi i Grci (Vallachi et Graeci), koji skandaliziraju narod time, što se na zabranjene dane hrane mesom.“124

Sačuvani su podaci o djelovanju trgovaca iz Koprivnice na ugarskom prostoru krajem 17. stoljeća. Godine 1692. u Ugarskoj je (najvjerojatnije u Veszprému) trgovao Stanon Mihalović, Racz von Caprünicz, za kojega se čini da je bio pravoslavni trgovac iz Koprivnice. ${ }^{125}$ Prema prometnom zapisniku carinarnice Siget, vidljiva je i nazočnost trgovaca iz hrvatskih slobodnih kraljevskih gradova.

122 O Legradu: Dragutin FELETAR, Legrad, Čakovec: KPD Zrinski, 1971; O Drnju: Hrvoje PETRIĆ, Općina i župa Drnje, Drnje: Nakladna kuća dr. Feletar, 2000.

123 Ranko SUČIĆ, Karmen LEVNIĆ, Ivana POSEDI, Zapisnici poglavarstva grada Koprivnice, sv. 1, Varaždin: Državni arhiv u Varaždinu, 2010., 40.

124 Nadbiskupijski arhiv Zagreb (NAZ). Kanonske vizitacije. Prot. 91/III. 74.

125 Slavko GAVRILOVIĆ, Građa o balkanskim trgovcima u Ugarskoj XVIII veka, knj. 2 -carinarnice, Beograd, 1996., str. 38. 
Tamo su ribom trgovali 1695. Blaž Puhalo i Andija Soković, obojica iz Koprivnice, i Ivan od Koprivnice (von Copreinitz) te drugom robom Martin Görös iz Zagreba, a 1696. Ivan Hersatović i Mitar Rac, obojica iz Koprivnice. ${ }^{126}$ Te nepovezane informacije mogu također biti prilog ukazivanju na pojačani intenzitet trgovine prema oslobođenim dijelovima Ugarske.

Kao primjer geografskog obuhvata trgovine prema Štajerskoj spomenimo problem oko izvoza meda preko Ptuja, gdje su na temelju stovarišnog prava zaustavljali hrvatsko-slavonske trgovce i ostale koji su izvozili med na način da su ih držali u Ptuju neograničeno vrijeme. Hrvatsko-slavonski sabor tražio je da se takav postupak s izvoznicima prekine te tamo izvezeni med kupi ili da im se dozvoli da ga otpreme dalje. Spor se zaoštrio kada je ptujska gradska općina na otvorenoj, slobodnoj cesti na lokaciji prilično udaljenoj od Ptuja počela plijeniti robu varaždinskih trgovaca. ${ }^{127}$ Godine 1640 . gradska općina Ptuj zadržala je iz Hrvatsko-Slavonskog Kraljevstva izvezeni med. Na to je Hrvatsko-slavonski sabor iste godine donio odluku da štajerski vinogradari neće smjeti prodavati vino na hrvatskom prostoru, a svaka trgovina vinom smatrat će se krijumčarenjem. Došlo je do svojevrsnog trgovinskog rata i određeno je da će se napraviti dvije kontrole: jedna na rijeci Dravi kraj Zavrča i blizu Ormoža, a druga kod Brežica i Mokrica. Dvije godine kasnije - 1642., na zasjedanju Hrvatsko-slavonskog sabora, donesen je zaključak da se strancima i seljacima iz inozemstva zabrani otkupljivanja meda u Hrvatsko-Slavonskom Kraljevstvu, očito radi zaštite domaće trgovine medom. Godine 1643. donesena je saborska odredba: „Nikako da netko od velikaša ili plemića, pa i svoj vlastiti med, ili kupljeni, odvozi ili prodaje u Ptuj, ili bilo kuda van granica Kraljevine. Zaključak za prekršitelja je predviđao oduzimanje meda. Ovako se ima postupati u pogledu meda sve do 25. studenoga, do blagdana Sv. Katarine, odnosno do odobrenja banova, da se med može prodavati po običaju u Ptuj." Godine 1648. predmet spora postaje i trgovina željezom. Do tada je postojao slobodan prolaz za trgovce u blizini Zavrča, no građani Ptuja zatvorili su ga. Kada su 29. siječnja 1648. trgovci iz Varaždina putovali u Štajersku radi kupoprodaje meda, prelazeći rijeku Dravu u blizini Zavrča, napali su ih neki građani Ptuja te su im oduzeli 61 posudu meda. Oštećeni varaždinski trgovci bili su: Matija Truppey, Kristrofor Naistater i Bartolomej Andriusz. Sljedeće, 1649., godine na istoj javnoj cesti, no bliže Ptuju, varaždinski su trgovci vozili veću količinu željeza, a Ptujčani su ih napali i oduzeli im robu. Ukupna vrijednost meda i željeza iznosila je 1.200 rajnskih forinti. ${ }^{128}$

\footnotetext{
$\overline{126}$ GAVRILOVIĆ, JAKŠIĆ, PECINJAČKI, Građa o balkanskim trgovcima u Ugarskoj XVIII veka, 1, 224-228.

127 Zlatko HERKOV, Povijest zagrebačke trgovine, 64.

128 ZHS 1, 146; Mirko ANDROIĆ, „Rat“ Varaždinaca i Ptujčana u 17. stoljeću, Kajkavski kalendar 1970, Čakovec, 1969., 107-110; HERKOV, Povijest zagrebačke trgovine, 64.
} 
Trgovački sporovi između Ptuja i Varaždina nastavili su se. Naprimjer 1659. Dvorska komora u Grazu tužila je trgovce iz Varaždina i Legrada da krijumčare, a Varaždinci su se tužili na Ptujčane da sprečavaju njihovu trgovačku djelatnost, njihovim trgovcima čine nepravdu te im oduzimaju robu. Ptujčani su se žalili da ne dobivaju dovoljno prihoda od maltarine zbog toga što su trgovci iz Varaždina i Legrada krijumčarili robu vozeći je skrovitim putovima do Ljubljane zaobilazeći ptujsku maltu. Trgovci iz Kranjske odlazili su u Varaždin, Legrad i Čakovec i tamo kupovali konje te su tajnim putovima zaobilazili Ptuj. Pomagali su im domaći ljudi po Štajerskoj, a u Celju ili Rogaškoj Slatini nitko ih nije pitao jesu li platili maltu u Ptuju. Ptujčani su tvrdili da je u zadnje vrijeme na taj način prokrijumčareno preko 3.000 koža, što je i za Ptuj i za Dvorsku komoru u Grazu predstavljalo znatan gubitak. Kada su iz Ptuja poslali 30 konjanika kako bi zaustavili krijumčarenje, krijumčari su otišli u Varaždin i Legrad. U izvještaju piše kako Varaždin nije pobirao takse te je trgovačkoj robi davao slobodan prolaz. Stoga su se trgovci platnom, suknom, paprom i drugom robom tamo skrivali. Dvorska je komora na zahtjev Ptuja naložila Kranjskoj da sprečava spomenuto krijumčarenje. ${ }^{129}$

Očito je sigurnost putovanja trgovcima povremeno bila na niskoj razini. $\mathrm{Hr}-$ vatsko-slavonski sabor na zasjedanju 23. listopada 1664. u Varaždinu odredio je da gradovi Varaždin i Zagreb stranim trgovcima koji posjećuju njihove godišnje sajmove radi zaštite od razbojnika osiguraju oružanu pratnju na dolasku i odlasku u Kraljevstvo, odnosno do Sutle i do Zavrča. To je trebalo vrijediti sve dok ne prestanu razbojništva. Osiguranje sigurnosti bilo je važno za Kraljevstvo jer su strani trgovci osiguravali prihode od tridesetnice. ${ }^{130}$

Na kraju nekoliko riječi o Senju, koji je bio u statusu slobodnog i kraljevskog grada tek od druge polovice 17. stoljeća te ga se ne može u cijelosti uspoređivati s ostalim hrvatskim slobodnim i kraljevskim gradovima kroz cijelo 17. stoljeće; ograničit ću se tek na nekoliko natuknica. Poznato je kako je jaka srednjovjekovna senjska trgovina opala nakon presijecanja kopnenih putova iz unutrašnjosti prema senjskoj luci. Početkom 17. stoljeća Habsburgovci su pokušali organizirati sječu drveća u šumama oko Senja radi prodaje Mletačkoj Republici. Djelatnost stranih trgovaca u Senju bila je gospodarski povezana i sa senjskim uskocima, a korist od trgovine imali su posrednici; ako je bila riječ o senjskim građanima ili plemstvu, onda su mogli koristiti olakšice koje su propisivali senjski statut, odnosno carinski cjenik. Valja istaknuti kako je opseg trgovine sa senjskim usko-

\footnotetext{
129 STLA, Innerösterreichischen Hofkammer, god. 1659; ILIJANIĆ, Nekoliko podataka o vezama Ptuja i Varaždina u 16. i 17. stoljeću, 292.

130 ZHS, 1, 287.
} 
cima bio daleko ispod opsega srednjovjekovne senjske trgovine, no Senjani su činili sve što je bilo u njihovoj moći u održavanju Senja kao trgovačkog središta. Početkom 17. stoljeća imamo zabilježene aktivnosti službenika senjskog trošarinskog ureda i senjskih trgovaca koji su nakon preusmjeravanja jednog broda iz Perasta ustrajali u tome kako su senjske povlastice i lučki porezi jednako vrijedni kao i riječki, unatoč nezadovoljstvu Habsburgovaca. To ne treba čuditi jer, iako su Habsburgovci još 1528. Senjanima dali privilegij da mogu slobodno trgovati po čitavoj kraljevini, Senj je ipak bio potencijalni konkurent habsburškoj luci Rijeka, pa njezinim vlasnicima nije bilo u interesu ohrabrivati oživljavanje senjske luke. Ipak, Senjani su od kralja Ferdinanda III. godine 1640. dobili novi statut kojim je, uz ostalo, regulirana i trgovina. Da se odnos Habsburgovaca promijenio, govori podatak kako je 1652. godine Senj uzdignut u status slobodnog i kraljevskog grada, a taj mu je status potvrdio i Ugarski sabor sedam godina kasnije. ${ }^{131}$ Senj je bio važan i kao distribucijsko središte za trgovinu solju ${ }^{132}$ prema unutrašnjosti. ${ }^{133}$

$\overline{131}$ Mile MAGDIĆ, Topografija i poviest grada Senja, Senj, 1877.; isti, Statut kralja Ferdinanda III. od godine 1640. za grad Senj, Vjestnik Kr. hrvatsko-slavonsko-dalmatinskog zemaljskog arkiva, 2, Zagreb, 1900., 78-97; isti, Povelja, kojom je kralj Ferdinand III. dne 23. veljače 1652. uvrstio grad Senj u broj kraljevskih i slobodnih gradova, Vjestnik Kr. hrvatsko-slavonsko-dalmatinskog zemaljskog arkiva, 2, Zagreb, 1900., 123-125; Mirko VALENTIĆ, Razvitak Senja u okviru Hrvatsko-slavonske Vojne krajine, Senjski zbornik: prilozi za geografiju, etnologiju, gospodarstvo, povijest i kulturu, 1, Senj, 1965., 69-93; Zlatko HERKOV, Carinski cjenik grada Senja od godine 1577., Vjesnik historijskih arhiva u Rijeci i Pazinu, 17, Rijeka, 1972., 45-78; Drago ROKSANDIĆ, Bune u Senju i Primorskoj krajini (1719-1722), Radovi Instituta za hrvatsku povijest, 15, Zagreb, 1982., Aleksandar BUCZYNSKI, Gradovi Vojne krajine, 1, Zagreb: Hrvatski institut za povijest, 1997., 162; Catherine Wendy BRACEWELL, Senjski uskoci, Zagreb, 1997., 108-118; Nataša ŠTEFANEC, Trgovina drvetom na Triplex Confinumu ili kako izvući novac iz senjskih šuma (1600-1630)?, Triplex Confinium (1500-1800): ekohistorija, Split - Zagreb, 2003., 337-363.

Željko HOLJEVAC, Hrvatsko-slavonska Vojna krajina u ranome novom vijeku, u: Željko HOLJEVAC i Nenad MOAČANIN, Hrvatsko-slavonska Vojna krajina i Hrvati pod vlašću Osmanskog Carstva u ranome novom vijeku, Zagreb: Leykam, 2007., 73.

I slobodni kraljevski grad Zagreb (Gradec) je još u srednjem vijeku bio važno prometno središte za distribuciju soli. Grad je uveo posebnu daću na morsku sol kao naknadu za vaganje soli koja se mijenjala ili prodavala. Ta naknada je u stvari bila uvoznina. Na značaj solne trgovine ukazuje to da se Gradec brinuo za posebna skladišta i trgovine za sol. Godine 1614. grad je imao prihode od mijenjanja soli sa Kočevarima, ali i od prodaje gradske (općinske) soli. I susjedni biskupsko-kaptolski Zagreb se služio morskom soli, koju dopremao lađama iz Dubovca ili iz Kranjske. Osim morske soli kupovala se i kamena sol, koja se uvozila iz austrijskih zemalja i Ugarske. PSZ, 19, 57, 61, 72, 246, 248, 265 itd; HERKOV, Povijest zagrebačke trgovine, 94. 


\section{Umjesto zaključka}

Poslovanje trgovaca u slobodnim kraljevskim gradovima Hrvatsko-Slavonskoga Kraljevstva tijekom 17. stoljeća bilo je ovisno o susjednim unutarnjoaustrijskim pokrajinama i sjevernoj Italiji, stoga su se iz tih područja doseljavali trgovci i stalno nastanjivali u Zagrebu, Varaždinu i Koprivnici. U djelovanju trgovaca u Varaždinu u znatnoj je mjeri vidljiva briga oko opskrbe vojnih posada Vojne krajine. Hrvatski slobodni i kraljevski gradovi tijekom 17. stoljeća nastojali su privući nove trgovce i ostale poduzetnike raznim olakšicama kako bi se ojačala ili oživila gospodarska djelatnost. Trgovački su se poslovi najčešće zasnivali na kupoprodaji, ali u trgovini su mogli doći u obzir i drugi pravni poslovi kao naprimjer zamjena. Takvim su se poslovima bavili ne samo trgovci nego i drugi poduzetnici. Sudionici u trgovini bili su: domaći trgovci, strani trgovci, obrtnici (domaći i strani), velikaši i plemići (te načelno svaki posjednik), seljaci iz okolice, preprodavači i prodavači kruha i živeži na trgu. 


\section{Summary}

\section{Trade in the Croatian Royal Free Cities in the $17^{\text {th }}$ Century}

In this paper, the author attempts to offer an insight into the trade in royal free cities of the Croatian-Slavonian Kingdom in the $17^{\text {th }}$ century. Based on the historiographic results achieved so far, as well as both published and nonpublished sources, the author primarily tackles the royal free cities: Zagreb (Gradec), Varaždin and Koprivnica, followed - to a lower extent - by Senj and Križevci. Trade in the Croatian royal free cities in the course of the $17^{\text {th }}$ century should be analysed in the context of economic processes taking place in a wider area. Towards the end of the $16^{\text {th }}$ century, trade traffic was extended to activities conducted between the continental interior and the littoral areas. Furthermore, at that time, the scope of trade activities was enhanced through the north Adriatic ports. Trade-related activities in the territory of the Croatian-Slavonian Kingdom depended in the $17^{\text {th }}$ century on the neighbouring Austrian continental provinces and on the Northern Italy. Hence, tradespeople from these areas chose to immigrate and permanently settle in Zagreb, Varaždin and Koprivnica. The principal centre of trade was Zagreb. In the context of the activities of tradespeople in Varaždin, supplying the military units of the Military Border was predominant, whereas Koprivnica, Senj and Križevci were towns in which civil and military authorities were intertwined. During the $17^{\text {th }}$ century, the Croatian royal free cities endeavoured to attract more tradespeople and other entrepreneurs by introducing diverse relaxations, in order to improve or revive the overall economic activity. Though trade activities were in the majority of cases based on buying and selling, other legal businesses, such as for instance barter, were an option too. Not only tradespeople, but also other entrepreneurs engaged in such activities. Participants in the trade were as follows: domestic tradespeople; foreign tradespeople; artisans (domestic and foreign); members of aristocracy and nobility (and, in fact, every landowner); peasants from the surrounding areas; resellers and sellers of bread and groceries on the square.

Keywords: trade; royal free cities of the Croatian-Slavonian Kingdom; $17^{\text {th }}$ century; fairs. 